Journal of Business \& Management (COES\&RJ-JBM)

ISSN (E): 2306-7179 ISSN (P): 2306-8043

Publisher: Centre of Excellence for Scientific \& Research Journalism, COES\&RJ LLC

Online Publication Date \& Issue: 1st July 2016, Vol.4, No.3, July 2016

http://centreofexcellence.net/J/JBM/JBM\%20Mainpage.htm

\title{
Export-led Growth Revisited in Emerging Economies
}

\author{
Assoc. Prof. Dr. Sule L. Aker \\ Eastern Mediterranean University \\ Tel: +90 (392) 6301260 \\ Fax: +90 (392) 3651017 \\ e-mail: sule.aker@emu.edu.tr \\ Prof. Ahmet Aker \\ Cyprus International University
}

\begin{abstract}
Today the world economic power is shifting from the West to the East. Some emerging economies are pulling the economic activities in the world more than ever. These countries are sometimes referred as E7, or 7 emerging economies. They are Brazil, China, India, Indonesia, Mexico, The Russian Federation and Turkey in alphabetical order. This paper analyzes the sources of the economic growth in these countries. In the model the exogeneous factors relating to economic growth are selected as exports and FDI. The endogeneous factors would be reflected in the employment rate. It is found out that most of these countries are growing by exporting. Therefore, it is concluded that the export-led growth paradigm is a viable economic growth model even today. The correlation between economic growth and FDI gives unexpected results. In all emerging economies, economic growth and FDI are negatively correlating, except in Russian Federation and in Turkey there is no correlation between the two variables. In China, economic growth correlates negatively with unemployment suggesting that endogeneous factors play an important role in Chinese economic growth.
\end{abstract}

\section{Keywords:}

Export-led growth, unemployment, exports, foreign direct investment, Brazil, China, India, Indonesia, Mexico, the Russian Federation, Turkey, emerging markets.

\section{Citation:}

Aker, Dr. Sule L.; Aker, Ahmet (2016); Export-led Growth Revisited in Emerging Economies; Journal of Business \& Management (COES\&RJ-JBM) Vol.4, No.3, pp.140150.

This work is licensed under a Creative Commons Attribution 4.0 International License. 


\section{INTRODUCTION}

The economic performance of emerging economies in the last decades has been impressive. The economic growth figures of these countries shattered many beliefs and paradigms relating economic growth to religion and culture. Weber's "Protestant Ethic" argument stating that the Protestant belief and value system is a precondition for economic growth, for example has proven to be wrong. Likewise, analysts categorizing Hinduism and Islam as religions responsible for the economic backwardness of countries can be considered short-sighted. As emerging markets' share in global income and output rise, many theories, assumptions and dogmas need to be revised or discarded altogether while some of the more staple theories like the theory of export led-growth seem to be validated.

This study is an exercise in testing the validity of the theory of export-led growth based on the recent development of the Emerging Economies. The basic question it tries to answer is: Is the model of export-led growth valid for the emerging economies as it was for the already industrialized developed countries?

Emerging economies are those countries that are growing and industrializing at a rapid speed in recent decades. The E7 countries are the seven largest economies of the emerging markets. They are Brazil, China, India, Indonesia, Mexico, Russian Federation and Turkey, in alphabetical order. The terminology is not standardized yet, nor are the countries in this group. However, because of the economic growth potential and the huge populations embedded in this category, E7 is considered a very important category following the G7. The Group of Seven consists of the United States (US), United Kingdom, France, Germany, Japan, Italy and Canada. The economic stagnation and recession in the G7 countries diverted the focus of attention to the E7 as these countries' economic growth figures continue to be relatively high. Table 1 shows the economic growth rates of the E7 countries. There is a drop in 2014 in the GDP growth rates of some countries like Brazil and the Russian Federation due to prolonged economic crisis, but the economic growth in most of E7 is still well above the developed countries' growth rates.

Table 1 - Recent GDPgrowth rates in E7 (annual percentage GDP growth)

\begin{tabular}{|l|l|l|l|l|l|l|l|}
\hline Countries & Brazil & China & India & Indonesia & Mexico & $\begin{array}{l}\text { Russian } \\
\text { Federation }\end{array}$ & Turkey \\
\hline 2010 & 7.5 & 10.3 & 9.7 & 6.1 & 5.5 & 4.0 & 9.0 \\
\hline 2011 & 2.7 & 9.1 & 6.9 & 6.5 & 3.9 & 4.3 & 8.5 \\
& & & & & & & 2.0 \\
\hline 2012 & 1.0 & 5.0 & 5.0 & 6.0 & 4.0 & 3.0 & 4.0 \\
\hline 2013 & 2.0 & 9.0 & 5.0 & 6.0 & 1.0 & 1.0 & 2.9 \\
\hline 2014 & 0.1 & 7.3 & 7.3 & 5.0 & 2.2 & 0.6 & \\
\hline
\end{tabular}

Source: World Development Indicators [1]

On top of their economic success, the E7 is also attracting attention, because they are recently organizing and forming a block in international organizations such as the World Trade Organization (WTO). With rapidly growing economies, huge populations and very large markets, it will not be surprising to see their influence increasing in global politics. 
One extremely relevant question is "what is behind the economic success of these emerging economies?" This is indeed the question being investigated in this paper. The most important finding of this study is that most of the E7 countries are growing by exporting, except Turkey and China's economic growth stems from endegeneous factors embedded in the employment figure. In this analysis, exogeneous factors are selected as exports and FDI and endegenous factors are represented by the unemployment rate. The economic growth rates of countries are tested for correlation with the exogeneous and endogeneous factors.

Export-led growth strategy seems to be an important venue for countries to achieve economic growth, even today. Export-led growth has been the most successful strategy to increase income and wealth of countries for decades. USA (1920-), Germany and Japan (1950-), Four Asian Tigers (1960-), China (1980-), India (1990-) and many others raised their GDPs through massive exporting. Export-led growth has been a major model for economic development in 1970's, especially after the spectacular economic success of the Four Asian Tigers (South Korea, Singapour, Hong Kong and Taiwan) [2]. However, after the global financial and later economic crisis of 2008, there were doubts whether export-led growth strategy would continue to be contributing to the economic growth of the emerging economies. Basically, two factors may pose a threat to export-led growth strategy; demand shortage in the developed countries and rising protectionism overall [3].

Yusuf argues that because of the excess production capacity of major industries in East Asia, crisis in the major consumer market the USA and rising energy and resource costs, the export-led growth paradigm may come to an end [4].

Table 2 shows the value of exports of E7 countries in US dollar amounts. The exports of all E7 countries show strong growth in exports.

Table 2 - Exports of E7 in (billion) US dollars

\begin{tabular}{|l|l|l|l|l|l|l|l|}
\hline & Brazil & China & India & Indonesia & Mexico & $\begin{array}{l}\text { Russian } \\
\text { Federation }\end{array}$ & Turkey \\
\hline 2010 & 232 & 1743 & 375 & 174 & 314 & 445 & 155 \\
\hline 2011 & 294 & 2088 & 448 & 223 & 365 & 576 & 185 \\
\hline 2012 & 283 & 2248 & 446 & 212 & 387 & 597 & 207 \\
\hline 2013 & 281 & 2439 & 465 & 206 & 400 & 594 & 201 \\
\hline 2014 & 270 & 2342 & 475 & 210 & 419 & 558 & 221 \\
\hline
\end{tabular}

World Development Indicators [5]

The rest of the paper is organized as follows: The theoretical framework section will be explaining the export-led growth paradigms, which will be followed by a literature review. In methodology section, economic growth and different macroeconomic variables in E7 are correlated using the multiple regression analysis. Conclusion and suggestions follow.

\section{THEORETICAL FRAMEWORK}

Export-led growth argument relies on the assumption that exporting brings in capital (one of the factors of production) which improves the financial endowments of a country. Thus, production possibilites frontier (PPF) moves outward signifying increased 
production possibilities in the country. This may be considered a first theoretical foundation of the export-led growth argument.

Another explanation relating exports and PPF is expressed by Keynesian equilibrium;

$$
\mathrm{Y}=\mathrm{C}+\mathrm{I}+(\mathrm{X}-\mathrm{M})
$$

where $\mathrm{Y}$ (national product and income) is composed of $\mathrm{C}$ (consumption), I (investments) and exports minus imports $(\mathrm{X}-\mathrm{M})$. As exports $(\mathrm{X})$ increase, national product and income grow.

The second theoretical foundation for the export-led growth argument is the assumption that exports bring productivitiy gains which in turn increases the total output. Increase in productivity means using the same amount of resources and producing more output, and/or using fewer inputs and producing the same amount of output. Marin found a correlation between exports and productivity for United States, Japan, United Kingdom and Germany, however productivity gains due to exports were very small in these four countries [6].

The third argument supporting export-led growth points out that as firms produce for export markets, they learn and adopt new technologies, use new processes and become more competitive. This will cause increases in production and sales.

The forth argument suggests that as firms produce for export markets, their production increase and they achieve economies of scale. Their per unit costs fall and profits rise. Consequently, their market shares grow inducing production growth in the home country.

There are however, three dangers to export-led growth; one is, if the country is small, increasing exports may lead to export-dependence. If the country's economy is too much dependent on its exports, then any change in the world demand for its exports will be affecting the country's economy at unwanted degrees. The changes in the world demand would induce fluctuations to the domestic economy increasing the instability. This danger is not too serious for the E7 countries, because all of them are big countries and a single export good can not have a determining effect on their economies.

The second danger in export-biased growth is "immiserizing growth". Immiserizing growth occurs when a country increases its exports of a good, the supply of this good increases in the world markets and its price falls, causing a fall in the export revenues of the country. However, this can not concern E7, because the fall in prices of the exports of these countries hurt the manufacturers in the developed countries more than the manufacturers in E7 countries, because the prices of many manufactured goods are higher in the developed countries. Thus the manufacturers in developed countries would be harmed by falling prices before the E7 countries.

The third danger is "Dutch Disease" or deindustrialization. When new natural gas fields were found under the North Sea in The Netherlands, resources were transferred from industry to natural gas production. "It seemed that the more the Netherlands developed its natural gas production, the more depressed its manufacturers of traded goods became" [7]. So one problem with increasing exports is while the country is increasing the production of the export good, the country could have retardation in other traditional domestic sectors. 


\section{LITERATURE REVIEW}

In many industrialized countries, high economic growth periods coincide with increase in exports . Between 1965-1973 for example, "the export volume of industrial countries grew twice as fast as that of developing countries" [8]. Even before, "by 1854 Britain was exporting over $20 \%$ of its GNP and the British share of world exports of manufactures was more than 40\%" [9]. However, exporting primary products did not bring similar results in developing countries. So what promoted economic growth in England should be exporting industrial products to the colonies. Exporting agricultural products will not bring huge export earnings if we look at the past experiences of many developing countries, and colonies.

Chang argues that no country has industrialized without trade protection, a special industrial policy and macroeconomic management [10]. In other terms, only after industrialization, exporting industrial products can be a substantial venue for economic growth. However, Park challenges this view and argues that trade liberalization helps the developing countries to industrialize faster than in autarky condition, because developing countries may purchase better intermediate goods and cheaper capital goods than if they are producing them themselves [11]. Moreover, the "disappointing experience" in Africa and the "disconnect between exports and broad-based growth" in Latin America show that the relation between exports and economic growth is not a very simple and straightforward one [12]. So which one should come before in time; industrialization or trade liberation? The Chinese example favors industrialization before trade liberalization.

Raja draws attention to the demand side and points out that big export markets are important and claims that because the USA constitutes 50\% of the world current account deficits, the slow down of US economy will cause contracting export market for emerging economies [13]. In other words, for E7 to export, big economies should be importing. However, contracting big markets do not necessarily mean that E7's exports to these markets will be decreasing. "Chinese exports to the US [is] soaring 23 percent in May [2012] from a year earlier" [14]. The demand for cheaper imported products may rise as a result of belt-tightening in developed markets, for example. Turkey on the other hand, diversified its export markets, increasing exports to United Arab Emirates, Iran, Bangladesh, Egypt, Libya and US to compensate the decrease in exports to the EU [15].

\section{METHODOLOGY}

Economic growth and various macroeconomic variables are correlated in the E7 countries. The hypothesis tested is that economic growth is a function of employment, exports and FDI. It is assumed that economic growth and unemployment (inversely), exports (direct proportionally) and FDI (direct proportionally) would be correlating in the E7 countries. Unemployment is selected to distinguish between endogeneous and exogenous factors correlating with countries' economic growth. If economic growth correlates (negatively) with the unemployment, then country's growth would be relating the endogenous factors. If economic growth correlates with exports and FDI, then the exogeneous factors would be playing a more important role in country's growth during the analyzed period, 1982-2014. Also, if the country's economic growth correlates with employment, the finding would suggest that domestic market plays a more significant role in aconomic growth of that country. Of course both endogeneous and exogeneous factors could be important for countries' growth, too. If economic growth and exports correlate, it is assumed that one of the factors behind economic growth in the country is 
exports. Then the export-led growth paradigm would be holding true in the country analyzed. So economic growth is the function of unemployment, exports and FDI:

$$
\mathrm{g}=\mathrm{f}(\mathrm{u}, \mathrm{x}, \mathrm{FDI})
$$

The multiple regression equation of the above hypothesis is shown in equation (1) where economic growth of the countries is the dependent variable and unemployment (unemployment rate as percentage of total labor force), exports (exports of goods and services in current US dollars) and FDI (net foreign direct investment (inflows minus outflows) in the balance of payments (BOP) in current US dollars) are the independent variables:

$$
\mathrm{g}_{\mathrm{i}}=\mathrm{a}_{\mathrm{i}}+\beta_{1 \mathrm{i}} \mathrm{U}_{\mathrm{i}}+\beta_{2 \mathrm{i}} \mathrm{X}_{\mathrm{i}}+\beta_{3 \mathrm{i}} \mathrm{FDI}_{\mathrm{i}}+\mathrm{e}_{\mathrm{i}}
$$

(1)

In countries like China where the economy of the country is big and economic growth is high, exports and FDI as percentage of the GDP revealed more meaningful outcomes.

$$
\mathrm{g}_{\mathrm{i}}=\mathrm{d}_{\mathrm{i}}+\beta_{1 \mathrm{i}} \mathrm{U}_{\mathrm{i}}+\delta_{2 \mathrm{i}} \mathrm{XP}+\delta_{3 \mathrm{i}} \text { FDIP }_{\mathrm{i}}+\varepsilon_{\mathrm{i}}
$$

(2)

Where;

$\mathrm{g}$ is the gross domestic product (GDP) annual percentage (\%) growth, $\mathrm{a}$ is the constant of the equation (1),

$\beta_{1}$ is the coefficient of correlation for unemployment,

$\mathrm{U}$ is the unemployment rate as percentage of total labor force,

$\beta_{2}$ is the coefficient of correlation for exports (X),

$\mathrm{X}$ is the exports of goods and services in current US dollars,

$\beta_{3}$ is the coefficient of correlation of FDI,

FDI is the net foreign direct investment (inflows minus outflows) in the balance of payments (BOP) in current US dollars,

$\mathrm{e}$ is the error term of the equation (1),

$\mathrm{d}_{\mathrm{i}}$ is the constant of the equation (2),

$\delta_{2}$ is the coefficient of correlation for XP,

$\mathrm{XP}$ is the exports of goods and services as percentage of GDP, $\delta_{3}$ is the coefficient of correlation for FDIP,

FDIP is the FDI net inflows as percentage of GDP,

$\varepsilon$ is the error term for equation (2),

$\mathrm{i}$ is the E7 countries; Brazil (Br), China (Ch), India (In), Indonesia (Is), Mexico (Me), Russian Federation (Rf), Turkey (Tu).

Results of the regression are as follows:

$$
\begin{aligned}
& \text { For Brazil, } \\
& \mathrm{g}_{\mathrm{Br}}=3.432-0.070 \mathrm{U}_{\mathrm{Br}}+0.744 \mathrm{X}_{\mathrm{Br}} \\
& (2)
\end{aligned}
$$

Table 3 - Coefficients for Brazil when GDP growth is the dependent variable:

\begin{tabular}{|l|l|l|}
\hline & t-value & Significance \\
\hline Unemployment & -0.340 & 0.737 \\
\hline
\end{tabular}


Export-led Growth....

\begin{tabular}{|l|l|l|}
\hline Exports (cur. US dollars) & 2.201 & 0.040 \\
\hline FDI net (cur.US dollars) & -2.433 & 0.025 \\
\hline $\mathrm{R}^{2}=0.256$ & \\
\hline
\end{tabular}

Economic growth and exports are positively correlating in Brazil and the t-value is 2.201 as summarized in Table 3. So we can say that the export-led growth hypothesis holds for Brazil. The significance of correlation is at $5 \%$ level which is 0.040 , and the coefficient of correlation for exports $\left(\beta_{2}\right)$ is 0.744 which is a high value. Economic growth and FDI are negatively and significantly correlating in Brazil which implies that as FDI increases, economic growth falls and the correlation is significant at 5\% level. This type of correlation is observed in developing countries where the foreign investors are allowed to transfer revenues and profits to home countries at extensive amounts. Also, foreign investments are concentrated in raw materials and minerals sectors. So as FDI increases, for example, more resources are transferred out of the country and economic growth falls. In Brazil, economic growth and employment do not correlate. So the endogeneous factor such as employment and economic growth are not closely related.

In China, equation (1) gives the following correlation:

$$
\mathrm{g}_{\mathrm{Ch}}=45.931-0.811 \mathrm{U}_{\mathrm{Ch}}-0.330 \mathrm{X}_{\mathrm{Ch}}-0.099 \mathrm{FDI}_{\mathrm{Ch}}+6.064
$$

Table 4 - Coefficients for China when GDP growth is the dependent variable:

\begin{tabular}{|l|l|l|}
\hline & t-value & Significance \\
\hline Unemployment & -5.814 & 0.000 \\
\hline Exports (cur. US dollars) & -0.842 & 0.411 \\
\hline FDI net (cur. US dollars) & -0.252 & 0.804 \\
\hline $\mathrm{R}^{2}=0.671$ &
\end{tabular}

As observed in Table 4, economic growth and unemployment are strongly and negatively correlating in China. The t-value is very high, -5.814, and the two variables are correlating 100 percent of the time. Also the coefficient of correlation is -0.811 showing strength of the relation between the two variables. The $\mathrm{R}^{2}$ is very high, so the equation explains the correlations to a high degree. So this result shows that Chinese economic growth has a strong domestic base.

For India,

$\mathrm{g}_{\text {In }}=7.483-0.035 \mathrm{U}_{\text {In }}+1.109 \mathrm{X}_{\text {In }}-1.066 \mathrm{FDI}_{\text {In }}+8.713$

(4)

Table 5 - Coefficients for India when GDP growth is the dependent variable

\begin{tabular}{|l|l|l|}
\hline & t-value & Significance \\
\hline Unemployment & -0.116 & 0.909 \\
\hline Exports (cur. US dollars) & 1.914 & 0.073 \\
\hline FDI net (cur.US dollars) & -2.105 & 0.050 \\
\hline $\mathrm{R}^{2}=0.240$ & \\
\hline
\end{tabular}

The export-led growth hypothesis hold for economic growth in India, too. T-value between economic growth and exports is 1.914 and the significance of correlation is 0.073 which shows a correlation for 93 percent of the time. The coefficient of correlation 
is 1.109 , implying that any increase in exports will be correlating with 1.109 growth in the Indian economy. On the contrary, economic growth and FDI are significantly and negatively correlating in India. Higher FDI correlates with economic contraction in India like in Brazil. The foreign firms are extracting and transfering more resources out of India than they bring in.

For Indonesia,

$$
\mathrm{g}_{\mathrm{Is}}=3.128-0.2 \mathrm{U}_{\mathrm{Is}}+1.334 \mathrm{X}_{\mathrm{Is}}-1.151 \mathrm{FDI}_{\mathrm{Is}}+3.491
$$

Table 6 - Coefficients for Indonesia when GDP growth is the dependent variable:

\begin{tabular}{|l|l|l|}
\hline & t-value & Significance \\
\hline Unemployment & -0.727 & 0.477 \\
\hline Exports (cur. US dollars) & 1.478 & 0.157 \\
\hline FDI net (cur. US dollars) & -1.281 & 0.216 \\
\hline $\mathrm{R}^{2}=0.126$
\end{tabular}

Export-led growth holds for Indonesia at $85 \%$ of the time. The t-value is 1.478 , which shows a weak correlation. $\mathrm{R}^{2}$ is also a low value. The variables in equation (6) are not explaining the factors correlating with economic growth in Indonesia very well. Nevertheless exports and economic growth correlates supporting the export-led growth hypothesis.

For Mexico,

$$
\mathrm{g}_{\mathrm{Me}}=4.820-0.717 \mathrm{U}_{\mathrm{Me}}+0.773 \mathrm{X}_{\mathrm{Me}}-0.371 \mathrm{FDI}_{\mathrm{Me}}+4.494
$$

Table 7 - Coefficients for Mexico when GDP growth is the dependent variable:

\begin{tabular}{|l|l|l|}
\hline & $\mathrm{t}$-value & Significance \\
\hline Unemployment & -1.435 & 0.182 \\
\hline Exports (cur. US dollars) & 1.770 & 0.107 \\
\hline FDI net (cur. US dollars) & -1.107 & 0.294 \\
\hline $\mathrm{R}^{2}=0.264$
\end{tabular}

The export-led hypothesis appears to be true also for Mexico. The t-value of the correlation between economic growth and exports is 1.770 and the significance is 0.107 (showing the two variables are moving together $90 \%$ of the time). The $\mathrm{R}^{2}$ is 0.264 implying that the explanatory value of the equation (8) is acceptable.

For The Russian Federation

$\mathrm{g}_{\mathrm{Rf}}=-24.513-0.160 \mathrm{U}_{\mathrm{Rf}}+0.681 \mathrm{XP}_{\mathrm{Rf}}+0.413 \mathrm{FDIP}_{\mathrm{Rf}}+6.788$

(9)

Table 8 - Coefficients for Russian Federation when GDP growth is the dependent variable:

\begin{tabular}{|l|l|l|}
\hline & t-value & Significance \\
\hline Unemployment & -0.865 & 0.399 \\
\hline Exports (\% of GDP) & 4.351 & 0.000 \\
\hline FDI net (\% of GDP) & 2.329 & 0.032 \\
\hline $\mathrm{R}^{2}=0.624$ & \multicolumn{2}{|l|}{} \\
\hline
\end{tabular}


The hypothesis holds for Russian Federation, too. Economic growth and export growth (as percentage of the GDP) are correlating for $100 \%$ of the time. The t-value is high; 4351. $\mathrm{R}^{2}$ is high, too. Another correlation is observed between economic growth and FDI (as percentage of the GDP). The two variables are correlating at $97 \%$. So economy expands as exports grow in Russian Federation and FDI is also contributing to the economic growth in the country.

For Turkey; thereis no correlation between the dependent and independent variables. Exports in dollar amounts, nor exports as percentage of GDP are correlating with the economic growth. No significant correlation between economic growth and unemployment, exports, FDI is obtained for Turkey. In many other studies, other researchers could not find a correlation between exports and economic growth in Turkey either. However, in some studies, there is a two-way causality relationship between economic growth and exports in Turkey [16]. It is also found that there is a correlation between economic growth and imports in Turkey, because Turkey is importing energy resources, raw materials, intermediate goods and capital goods for production which in turn influences the growth rate [17].

Table 3 - Results of the regressions of independent variables; unemployment, exports (goods and services in US dollars) and FDI (inflows minus outflows in the BOP in current US dollars), where economic growth is the dependent variable

\begin{tabular}{|c|c|c|c|c|c|c|c|c|c|c|}
\hline \multirow{3}{*}{ Countries } & \multicolumn{9}{|c|}{ Coefficients } & \multirow{3}{*}{$\begin{array}{l}\mathbf{R} \\
\text { square }\end{array}$} \\
\hline & \multicolumn{3}{|c|}{$\begin{array}{l}\text { Unemployment } \\
\text { (percentage of the } \\
\text { labor force) }\end{array}$} & \multicolumn{3}{|c|}{$\begin{array}{l}\text { Exports } \\
\text { dollars) }\end{array}$ (in $\quad$ US } & \multicolumn{3}{|c|}{$\begin{array}{l}\text { FDI (inflows minus } \\
\text { outflows in current } \\
\text { US\$) }\end{array}$} & \\
\hline & beta & $\begin{array}{l}\text { t- } \\
\text { value }\end{array}$ & Sig. & beta & t-value & Sig. & beta & t-value & Sig. & \\
\hline Brazil & $\begin{array}{l}- \\
0.070\end{array}$ & $\begin{array}{l}- \\
0.340\end{array}$ & $\begin{array}{l}0.7 \\
37\end{array}$ & $\begin{array}{l}0.74 \\
4\end{array}$ & 2.201 & $\begin{array}{l}0.0 \\
40\end{array}$ & -0.803 & -2.433 & $\begin{array}{l}0.02 \\
5\end{array}$ & 0.256 \\
\hline China & $\overline{0.811}$ & 5.814 & $\begin{array}{l}0.0 \\
00\end{array}$ & $\begin{array}{l}- \\
0.33 \\
0\end{array}$ & -0.842 & $\begin{array}{l}0.4 \\
11\end{array}$ & -0.099 & -0.252 & $\begin{array}{l}0.80 \\
4\end{array}$ & 0.671 \\
\hline India & $\begin{array}{l}- \\
0.035\end{array}$ & $\begin{array}{l}- \\
0.116\end{array}$ & $\begin{array}{l}0.9 \\
09\end{array}$ & $\begin{array}{l}1.10 \\
9\end{array}$ & 1.914 & $\begin{array}{l}0.0 \\
73\end{array}$ & -1.066 & -2.105 & $\begin{array}{l}0.05 \\
0\end{array}$ & 0.240 \\
\hline Indonesia & 0.200 & - & $\begin{array}{l}0.4 \\
77\end{array}$ & $\begin{array}{l}1.33 \\
4\end{array}$ & 1.478 & $\begin{array}{l}0.1 \\
57\end{array}$ & -1.151 & -1.281 & $\begin{array}{l}0.21 \\
6\end{array}$ & 0.126 \\
\hline Mexico & $\begin{array}{l}- \\
0.717\end{array}$ & $\overline{1.435}$ & $\begin{array}{l}0.1 \\
82\end{array}$ & $\begin{array}{l}0.77 \\
3 \\
\end{array}$ & 1.770 & $\begin{array}{l}0.1 \\
07\end{array}$ & -0.371 & -1.107 & $\begin{array}{l}0.29 \\
4 \\
\end{array}$ & 0.264 \\
\hline
\end{tabular}

Table 4 - Results of the regressions of independent variables; unemployment, exports (as percentage of GDP) and FDI (as percentage of GDP), where economic growth is the dependent variable

\begin{tabular}{|c|c|c|c|c|c|c|c|c|c|}
\hline & \multicolumn{8}{|c|}{ Coefficients } & \multirow{3}{*}{$\begin{array}{l}\mathbf{R} \\
\text { square }\end{array}$} \\
\hline \multirow[t]{2}{*}{ Countries } & \multicolumn{2}{|c|}{$\begin{array}{l}\text { Unemployment } \\
\text { (percentage of the } \\
\text { labor force) }\end{array}$} & \multicolumn{3}{|c|}{$\begin{array}{l}\text { Exports (percentage } \\
\text { of GDP) }\end{array}$} & \multicolumn{3}{|c|}{$\begin{array}{l}\text { FDI (percentage of } \\
\text { GDP) }\end{array}$} & \\
\hline & beta & Sig. & beta & t-value & Sig. & Beta & t-value & Sig. & \\
\hline
\end{tabular}


Journal of Business \& Management (COES\&RJ-JBM), 4(2), pp. 140-150

\begin{tabular}{|c|c|c|c|c|c|c|c|c|c|c|}
\hline & & value & & & & & & & & \\
\hline $\begin{array}{l}\text { Russian } \\
\text { Fed. }\end{array}$ & $\overline{0.160}$ & $\overline{0.865}$ & $\begin{array}{l}0.3 \\
99\end{array}$ & $\begin{array}{l}0.68 \\
1\end{array}$ & 4.351 & $\begin{array}{l}0.0 \\
00\end{array}$ & 0.413 & 2.329 & $\begin{array}{l}\text { 0.0. } \\
32\end{array}$ & 0.624 \\
\hline
\end{tabular}

\section{Conclusion}

If managed cleverly, the export-led growth strategy seems to be one of the driving forces behind the fast and continuous economic growth of the E7 countries. In Table 4, the correlation between economic growth and exports is revealing that some strongly, some weakly, but most E7 countries are growing with exports supporting the export-led growth hypthesis. Only in Turkey the hypothesis is not holding. FDI (exogeneous factor) is negatively correlating with economic growth in all countries except in the Russian Federation and in Turkey there is no correlation. The researh can be improved if some other endogenous variables like domestic savings are included in the analysis.

The global crisis and contracting demand in the USA and Europe may pose a challenge for the sustainability of this strategy. However, most of the E7 countries kept their export levels and/or increased their exports in the recent years. The explanation can be that with falling incomes, the consumer demand for the cheaper imports coming from E7 are increased in the West.

A more important threat to export-led growth strategy may come from rising protectionism in developed markets. However, trade protectionism cuts on both ways. While protecting the producers, the protectionist governments may lose the support of their exporters. Therefore, protectionism can become a difficult tool to employ in the short-term.

\section{REFERENCES}

[1] [5] World Development Indicators. http://data.worldbank.org/data-catalog/worlddevelopment-indicators

[2] [3] Palley, Thomas I., 2011. The Rise and Fall of Export-Led Growth. Working Paper No. 675, Levy Economics Institute of Bard College. http://www.levyinstitute.org/pubs/wp_675.pdf.

[4] Yusuf, Shahid, 2010. The Past and Future of Export-led Growth. http://blogs.worldbank.org/growth/past-and-future-export-led-growth

[6] Marin, Dalia, 1992. Is the Export-Led Growth Hypothesis Valid for Industrialized Countries? Review of Economics and Statistics, 74(4): 678-688.

[7] Pugel, Thomas A. and Peter H. Lindert, 2000. International Economics, eleventh ed. Mc Graw-Hill Companies, Inc., USA, p. 85.

[8] Chacholiades, Miltiades, 1990. International Economics. McGraw-Hill, Inc., Singapore, p. 133.

[9] Deane, P. and Cole W. A., 1969. British Economic Growth, 1688-1959. Cambridge University Press, Cambridge, p. 33. 
[10] Chang, H. J., 2002. Kicking Away the Ladder: Development Strategy in Historical Perspective. London, UK: Anthem Press.

[11] Park, Jee-Hyeong, 2011. Trade-induced Industrialization and Economic Growth. International Economic Journal, 25(3): 513-545. September issue, Routledge Taylor and Francis Group.

[12] Zepedo, Eduardo, Aldo Caliari, Otaviano Canuto, Marco James Kassaja, James Kiiru, Jorge Mattar, Terry McKinley, Luciano Mermet, 2009. Export-Led Growth as a Tool for Financing Development: Is the Financial Crisis Revealing its Limits? Carnegie Enowment, June 29, 2009.

http://www.carnegieendowment.org/2009/06/29/export-led-growth-as-tool-for-financingdevelopment-is-financial-crisis-revealing-its-limits/7or

[13] Raja Kanaga, 2010. Rethink export-led growth paradigm, says UNCTAD. Third World Resurgence, issue no. 240/241, August/September 2010.

[14] Bradsher, Keith, 2012. Selling Abroad, China Eases Slump at Home. The New York Times, Global Business, June 2012. http://www.nytimes.com/2012/06/11/business/global/with-surge-in-exports-china-easeseconomic-slump-at-home.html?pagewanted=all\&_r=0

[15] Çağlayan, Zafer, 2012. Avrupa ve Orta Doğu'daki Gelişmeler İhracatı Etkiledi. EkoAvrasya, Güz 2012, p. 57.

http://www.ekoavrasya.net/dergi/dergi-20/sayi20.pdf

[16] Bilgin, Cevat and Ahmet Sahbaz. Causality Relations between Growth and Export in Turkey. MPRA Paper No. 21985, posted 09. April 2010 / 11:05.

http://mpra.ub.uni-muenchen.de/21985

[17] Aker, Sule L., 2008. Major Determinants of Imports in Turkey. Turkish Studies, 9(1): 131-145. March 2008, Routledge, Taylor and Francis Group. 